\title{
E-LEARNING TECHNOLOGY IN THE PROCESS OF CLIL AT SCHOOL
}

\author{
Gulden Akbayeva ${ }^{1}$, Maxat Zhumassatuly ${ }^{2}$, Zhadyragul Bakmaganbetova ${ }^{3}$
}

\author{
${ }^{1,2,3}$ E.A. Buketov Karaganda University, Karaganda, Kazakhstan
}

ORCID ID ID: 0000-0002-0314-0944

\begin{abstract}
E-learning is a learning system based on formalized teaching but with the help of electronic resources (Asad et al., 2020). The article is devoted to the consideration of the idea of content and language integrated learning (CLIL) in the system of education and the analysis of new concepts and approaches of school education developed in methodological science, taking into account their influence on the motivation of school students to learn English language. The revitalization of the educational activity has always been one of the primary tasks of teaching in general. The CLIL methodology is compared with the ESP and EMI methodologies. This learning model does not imply a complete rejection of traditional teaching methods and combines both the advantages of face-toface studies (contact with a teacher, group methods of work, language and speech practice, the possibility of feedback) and the advantages of distance learning (an individual approach, differentiation of learning, ample opportunities for the implementation of project activities, optimization of independent work, the formation of language and speech skills and abilities. Modern teaching aids, including e-distance learning tools, provide teachers with ample opportunities for implementing a competency-based approach, providing a comprehensive all-around development of a school student's personality through the subjects studied. With the help of distance educational technologies, it is possible not only to shift a number of routine pedagogical actions onto the shoulders of a computer but also to organize high-quality, individual, differentiated education. The article presents strong theoretical information about CLIL and its importance. Also, the article contains results of qualitative research with conducted questionnaires among school students in grades 10-11 of a general education school.
\end{abstract}

\section{INTRODUCTION}

Currently, specialists who speak one or more foreign languages are highly valued, both in terms of everyday communication and in the professional field. This need is due to the rapid process of globalization of society. The last decade in European countries has received active development of integrated teaching of foreign languages and professional disciplines or content-language integrated learning. In Kazakhstan's schools, this technique is just beginning its journey and strives to take its well-deserved place in the curricula of the best educational institutions. Content and language integrated training is one of the most effective ways to establish interdisciplinary ties and successfully prepares a future specialist for foreign language professional communication [Masters, 2019].

One of the main advantages promoted by the proponents of this approach is the increased motivation of school students as a result of participation in such programs. Since motivation is one of the most influential individual variables when it comes to learning, it is assumed that the benefits of this approach are clear. However, there is insufficient research to support differences in motivation when comparing traditional teaching English as a foreign language versus content and Language Integrated Learning (CLIL) [Masters, 2019]. The main objectives of the study were as follows:

1) consider the theoretical aspects of approaches developed in Russian science within the framework of subject-language integrated learning [Nikolić et al., 2019];

2) analyze the practical application of this methodology in Russian education [Fandiño et al., 2019];

3) to consider the influence of the approach of subject-language integrated learning on the process of teaching foreign languages to school students of non-linguistic specialties [Rahim \& 
Chandran, 2021]. There are three most common integrated subject-language approaches [Asad et al., 2020]:

- ESP (English for specific purposes English for specific purposes);

- CLIL (Content and language integrated learning);

- $\quad$ EMI (English as Medium of Instruction).

\section{DISCUSSION}

Some researchers prefer CLIL, replacing it with the term ESP, which is widely known in the method of teaching a foreign language. In addition, the terminological picture is complicated by the concept of EMI existing in the methodology of higher education [Zozie, 2020]. All three terminological concepts are used in teaching a professionally-oriented foreign language, in which linguistic and purely special content aspects can be combined to varying degrees. In connection with the closeness of these three methodological categories, it becomes necessary to differentiate them.

English for Special Purposes (ESP) is "a functional type of language that contributes to the successful and adequate communicative act of specialists in various subject areas". Studies have shown that learning English through the ESP approach includes discipline preparation, discipline immersion, and an advanced course. The main objective of the ESP program is to develop the language competence of school students [Masters, 2019]. The training is aimed at improving foreign language communication skills, the level of knowledge of terminology, grammar and discourse features used in the professional sphere is assessed.

Content and Language Integrated Learning (CLIL) was developed by a group of scientists from European schools, among which the following can be noted: David Marsh, Do Coyle, Oliver Meyer, Victor Pavon, etc. on two subjects of the educational program. At the same time, a foreign or second language of school students, in which the entire course of study is conducted, is used as a means of teaching a discipline. At first glance, it seems that CLIL has no fundamental differences from other similar techniques. In fact, this approach works in the same plane with the language component and the professionally-oriented content of the profile discipline, without highlighting the more important of the two components.

Western teachers, who were among the first to introduce the CLIL approach into their practice, in their articles paid special attention to increasing the motivation of both sides: both the foreign language teacher and the student [Waluyo, 2020]. Some school students characterize CLIL as an "Investment in the development of their personality", especially note the opportunity to study new disciplines without thinking about the language [Fandiño et al., 2019]. Within the framework of this methodology, much attention is paid to the cognitive concept, which is based on the creation of an effective learning environment, within which the development of cognitive abilities is activated in school students. The introduction of CLIL, according to Asad et al., requires serious changes in the competence and the teacher himself, working on the basis of the principles of this approach.

English as the main language of instruction (EMI) is actively used all over the world in the form of a number of models, such as theme-based courses, linked courses, sheltered subject matter instruction, etc. Theme-based courses are theme-based courses delivered in a strange language by a linguistic teacher who does not require knowledge of specific subjects. This EMI model includes various topics of core subjects in the content. This approach serves as a tool for integrating the language into the content of the profile course, without overloading school students with subject content to the detriment of linguistic aspects [Masters, 2019]. This course focuses on the development of oral speech skills within the professional, cultural and educational-cognitive spheres of communication, mastering professional terminology and scientific vocabulary, developing the skills of reading special and scientific literature in order to extract information that is meaningful to the school student.

Linked courses are a variant of subject-language integrated learning, in which specialized disciplines are implemented in a foreign language [Fandiño et al., 2019]. The main difference of this model is for teaching purposes, which cover language skills for a language teacher, conceptual and conceptual aspects for a subject teacher. 
Sheltered subject-matter instruction is another type of profile course in a foreign language, integrated into the content of professional education and aimed at mastering a profile subject in a foreign language. This model is successfully implemented in groups of school students, where foreign students study, who know a foreign language worse than the main contingent of school students, and who need to be brought to a general level by using adapted or simplified language models. The implementation of the course can be carried out by a subject teacher with a level of knowledge of a foreign language below B2 (CEFR scale), less often by a language teacher who has additional education in a particular subject area. To study within the framework of this model, a certain level of foreign language competence of school students is required, since the priority area here is a professionally-oriented component and not a linguistic phenomenon.

The following methods of implementation and implementation of approaches and models of interdisciplinary integration were developed:

1. Creation of interdisciplinary pedagogical tandems and clusters.

2. Pedagogical support system for language learning in the classroom in professional disciplines.

3. Pedagogical support system for subject teaching in foreign language classes.

4. Formation of interdisciplinary themes and projects of the year.

5. Development of a profile course in a foreign language, integrated into the content of profile education.

Consider the features of each of the approaches presented. The first focuses on the content of teaching, the development of teaching tools, improving the quality of teaching and the effectiveness of teaching students a professional language. As a result of the work of such tandems, joint educational and methodological complexes in the professional language were created. The following types of interaction between the teaching staff have proven their effectiveness:

1) teachers of foreign language departments had access to practical classes in specialized disciplines, due to which a full familiarization with the content of the course was achieved [Asad et al., 2020];

2) teachers from the profiling department develop educational and methodological support of the course together with teachers of a foreign language, taking into account the specialization of the graduate [Fandiño et al., 2019];

3 ) throughout the training, constant contact with teachers of specialized disciplines is ensured when working with the lexical part of the course and the selection of professionally oriented literature for school students [Septinawati et al., 2020].

The need to conduct lectures in the EMI format turned out to be a real problem for both parties: teachers and students since foreign language competencies were not sufficiently developed [Yudina \& Dybchynska, 2019]. While professors had to repeat their English in specially organized linguistic courses, students also had to be ready for lectures in their subject matter in English.

Analysis of the literature showed that there are no ready-made solutions or universal recommendations to overcome the many difficulties on the way to implementing the EMI format in higher education. Problems include school students 'and teachers' inadequate English proficiency in understanding lectures in English as effectively as in their native language; difficulties in finding ways of effective cooperation between teachers of foreign languages and teachers of special disciplines in order to develop teaching materials and improve knowledge of the English language, both by students and teachers.

A survey was conducted in the form of an anonymous questionnaire (the questionnaire was compiled by the author) of school students in grades 10-11 of a general education school in the EMI format to identify the impact of this method on the development of foreign language competence. School students were offered a questionnaire of 20 questions.

According to the results of testing among students, $71 \%$ of the respondents gave a positive assessment of the foreign language course. $15 \%$ of the respondents are dissatisfied with the program due to the difficulty of perceiving specialized disciplines in a foreign language. The rest of the students find it difficult to answer, as they do not study long enough to evaluate the program. 
$53 \%$ of students note the full-fledged mastery of specialized subjects in English without using Russian-language literature. $41 \%$ of the respondents feel the need to use domestic teaching materials when preparing for exams and tests.

$87 \%$ of students said that subject-language integrated learning contributes to the activation of the process of learning a foreign language, noting that the level of language proficiency increases with each course of the program. $1 \%$ of respondents do not notice the influence of this technique on their level of knowledge of a foreign language. At the same time, 93\% of students feel the need to improve their foreign language competence. $76 \%$ of students note that participation in seminars in English helps to overcome the psychological barrier in the use of English in speech.

According to the survey results, $46 \%$ of respondents consider the opportunity to communicate in English abroad to be the main motivating factor; 32\% believe that English will be useful for their future work; $11 \%$ of students want to improve their knowledge; $6 \%$ of respondents like English, which is due to intrinsic motivation; for $5 \%$ of students, the main motivating factors are getting credit and passing the exam.

In addition, according to the results of the survey, a change in the motivation of students with regard to time was revealed. Namely, $61 \%$ of respondents in secondary school did not attach sufficient importance to a foreign language and treated the subject as a compulsory discipline. In this case, the main motivation was getting a positive assessment. Motivation changed after six months of study in the program in question. Therefore, $80 \%$ of students want to continue to study English after the 3rd year, and some, with high intrinsic motivation, are ready to study it all their lives. At the same time, $5.4 \%$ of students would not like to study English. Low or lack of motivation can be attributed to various reasons:

1) English will not be needed in future work;

2) a lot of workload with other subjects;

3) sufficient knowledge is available;

4) preference is given to another foreign language.

Thus, the survey revealed the predominance of factors of external motivation, namely, the possibility of using their knowledge and communication skills for communication, both in a broad sense and in future professional activities. The survey results also confirm the author's assumption that the application of the methodology of subject-language integrated learning stimulates school students to learn a foreign language.

\section{CONCLUSION}

Based on the foregoing, we can conclude that the technologies of subject-language integrated learning contribute to the activation of the process of mastering foreign language competencies based on the active integration of a foreign language with the process of teaching professionally significant disciplines. Students, already have an understanding of the basic concepts of the subject, since it is part of the curriculum, it is easier to perceive it in a foreign language. This reduces the uncertainty of using foreign language media to convey content and professional opinion. In addition, students' attention is diverted from the problems associated with the fear of making language mistakes, since their main efforts are directed to the subject content of the discipline.

For the formation of the communicative competence of school students, it is important to provide them with the opportunity to think in a foreign language, to solve any problems that generate thought in a foreign language, which acts in its direct function of forming and formulating these thoughts. At the same time, a prerequisite for communication is the use of scientific terms in their specialty.

The use of subject-language integrated learning is advisable when teaching school students in technical and economic fields, since learning a foreign language is often not a priority for them: "the purpose of reading students of non-linguistic specialties is not so much the language material as the information contained in it." That is why the use of the format of subject-language integrated education for students of non-linguistic areas is one of the factors that increase and stimulate educational and cognitive activity. 
Thus, Content and Language Integrated Learning (CLIL) when used systematically, contributes to a significant increase in motivation as the main mechanism for activating the process of teaching foreign languages to school students, since their attention is involuntarily held on interesting, new and meaningful language material [Olugbara \& Letseka, 2020]. The professionallyoriented subject of the classes meets the cognitive needs of students and leads to the active assimilation of new knowledge [Erusalimov et al, 2021]. They develop the ability to communicate in a business environment in a foreign language on issues of their competence. At the same time, the level of training of school students in a foreign language at non-linguistic faculties significantly increases, which, in turn, increases the competitiveness of a future specialist in modern conditions of tough competition in the labor market.

\section{REFERENCES:}

Asad, M. M., Hussain, N., Wadho, M., Khand, Z. H., \& Churi, P. P. (2020). Integration of e-learning technologies for interactive teaching and learning process: An empirical study on higher education institutes of Pakistan. Journal of Applied Research in Higher Education.https://doi.org/10.1108/JARHE-04-2020-0103

Erusalimov, R., Stoykova, P., Nestorov, L., Panteleeva, I., Marinov, M. (2021). Increasing the financial literacy and economic culture of students in grades 5-10. ISBN 978-954-23-1948-1, D.A. Tsenov Academy of Economics, Svishtov

Fandiño, F. G. E., Muñoz, L. D., \& Velandia, A. J. S. (2019). Motivation and E-Learning English as a foreign language: A qualitative study. Heliyon, 5(9), e02394. https://doi.org/10.1016/j.heliyon.2019.e02394

Masters, S. S. (2019). Integrating E-Learning in the Teaching of English Language Classes. In English Language Teaching in a Post-Method Paradigm (pp. 227-253). IGI Global. DOI: 10.4018/978-1-5225-9228-0.ch010

Nikolić, V., Petković, D., Denić, N., Milovančević, M., \& Gavrilović, S. (2019). Appraisal and review of e-learning and ICT systems in teaching process. Physica A: Statistical Mechanics and its Applications, 513, 456-464.https://doi.org/10.1016/j.physa.2018.09.003

Olugbara, C. T., \& Letseka, M. (2020). Factors Predicting Integration of E-Learning by Preservice Science Teachers: Structural Model Development and Testing. Electronic Journal of e-Learning, 18(5), pp421-435. https://doi.org/10.34190/JEL.18.5.005

Rahim, M. N., \& Chandran, S. S. C. (2021). Investigating EFL Students' Perceptions on E-learning Paradigm-Shift During Covid-19 Pandemic. Elsya: Journal of English Language Studies, 3(1), 56-66. https://doi.org/10.31849/elsya.v3i1.5949

Septinawati, S., Febriani, R. B., Tarwana, W., \& Syafryadin, S. (2020). Students' Perceptions Toward the Implementation of Quipper School as an E-Learning Platform in Teaching English. Jadila: Journal of Development and Innovation in Language and Literature Education, 1(2), 223-238. https://doi.org/10.52690/jadila.v1i2.103

Waluyo, B. (2020). Learning outcomes of a general English course implementing multiple e-learning technologies and active learning concepts. Journal of Asia TEFL, 17(1), 160.http://dx.doi.org/10.18823/asiatefl.2020.17.1.10.160

Yudina, O., \& Dybchynska, Y. (2019). Model of integrated teaching management core courses in a foreign language using ICT. Management and Entrepreneurship: Trends of Development, 2(08), 68-76. https://doi.org/10.26661/2522-1566/2019-2/08-06

Zozie, P. A. M. (2020). Integrating e-learning technologies into conventional teaching and learning in the school and higher education system with scarce resources: a case study of Mzuzu University (Doctoral dissertation, University of Glasgow).http://theses.gla.ac.uk/id/eprint/81397 